\title{
Public sector employment, class mobility, and differentiation in a tribal coal mining village in India
}

Itay Noy

Anthropology Department, London School of Economics, London, UK

India's adivasi, or tribal, communities have most often been depicted as homogeneous and egalitarian, at least compared to the entrenched social hierarchies that characterise rural caste society. This article draws on fieldwork in a mining-affected adivasi village in Jharkhand, eastern India, to consider how compensatory public sector employment for mining-induced land dispossession has contributed to new processes of stratification within adivasi society. On the one hand, compensatory employment allowed those who attained it to pursue increasingly common middle-class aspirations, and a considerable degree of class mobility. But on the other hand, it fostered new, enhanced forms of intra-adivasi differentiation - not only in terms of income but also consumption and lifestyle, education and children's life chances, and household and gender dynamics. New internal disparities, in turn, have acted to erode pre-existing elements of adivasi society that revolve around values of egalitarianism.

Keywords: India; coal mining; dispossession; inequality; adivasi

Nestled in one of India's coal-bearing regions, in the eastern state of J harkhand, the adivasi (tribal) village of Karampot is populated mostly by mud and some rudimentary pukka (brick) houses. From this pack of dwellings, however, a small number of structures incongruously stick out: large, gated cement-built houses often with a bright colourful exterior, and a large motorbike, car, or even SUV parked in the courtyard. Only ten or so years ago, such glaring variation in housing was not in existence; its emergence reflects some of the transformations brought about by the relatively recent onset of mining operations in Karampot's vicinity. 
Inhabited by adivasis from the Santal tribe, the largest in the state, Karampot lies next to Pandu Project, an opencast colliery managed by the state-owned Central Coalfields Limited (CCL). Its many earthen houses are inhabited by Santals who, faced with a lack of employment options in the colliery as well as area more generally, eke out a living by illegally scavenging coal from it which they carry on bicycles to peddle on the adjacent highway. The village's much smaller number of cement houses, by contrast, belong to a minority of Santal villagers who have a naukri (job) in the colliery: permanent, secure employment with a monthly salary. Such employment in Karampot is the result of land expropriation for mining, and is held only by a small number of villagers. The households who have it are, in fact, not originally from Karampot but from Dharutar - a neighbouring and now displaced Santal hamlet whose tracts had been expropriated by CCL for the construction of Pandu Project. J obs in the project were consequently meted out to these households by the company as part of its Resettlement and Rehabilitation (R\&R) policy, which aims to provide employment to villagers who lose a certain amount of land to mining (CCL 2008).

Based on 18 months of ethnographic fieldwork in Karampot, this article explores the impact of public sector employment on the lives of the Santals who gained it, and the ways in which they are distinguished from those of all other, coal-peddling villagers. The attainment of compensatory jobs, it is argued, has had a contradictory impact. On the one hand, it allowed employed Santals a considerable degree of class mobility - by which I mean, specifically, entry into labour aristocracy of public sector employment, with high levels of security and pay (Parry 2013b, 2019). But on the other hand, compensatory public sector jobs fostered the emergence of new internal disparities between employed and non-employed villagers - not only in terms of income but also consumption, children's life chances, and household and gender dynamics. By contrast with rural caste society, characterised by stark inequalities along caste, class, and gender lines, adivasi communities have been commonly viewed as considerably more homogeneous and egalitarian (Levien 2013; Shah \& Lerche 2017; Srivastava 2008; Sundar 2001; Xaxa 2011: 15). Studies on inequality in the adivasi context, on their part, have focused primarily on the (re)production of disparities between adivasis and their non-tribal counterparts (e.g. Lerche \& Shah 2018; Nathan \& Xaxa 2012; Shah et al. 2017; Throat 2010). This article, by contrast, 
considers the comparatively little explored processes of intra-adivasi differentiation', and its corrosive outcomes for long-held adivasi egalitarian values.

Adivasi egalitarian characteristics, Alpa Shah (2018) notes, have traditionally manifested in relatively low and usually temporary economic differences between households. Indeed, prior to the arrival of mining, Karamopt was a village in which households reproduced themselves on relatively egalitarian terms: there were no considerable landholding disparities, and practically all households relied for their livelihood on a combination of small-scale subsistence agriculture and casual wage labour outside the village. Overall socioeconomic conditions, in other words, were precariously similar, as the types of work in which households engaged did not allow any of them to achieve a significant level of security and accumulation. Importantly, this is not to argue that there was no differentiation whatsoever between Santals - or other adivasi groups, for that matter. Still, compared to rural caste society, adivasi communities - including in Karampot - were comparably free from unequal social and class divisions (ibid.; see also Bailey 1961; Shah \& Lerche 2017: 27). This was based not only on more egalitarian material conditions but also values, expressed in adivasi practices such as madaiti - non-monetary labour exchange between households, for example in house building and field sowing; and gender relations, with both sexes working in and outside the household, and relatively equal in status.

Uneven access to the benefits of mining industrialisation, however - specifically, compensatory public sector jobs - has given rise to new, salient forms of socioeconomic and class differentiation ${ }^{2}$, which has progressively resulted in the erosion of these pre-existing features and values of egalitarianism.

\section{Background}

In central and eastern India, mining operations have been largely concentrated in areas inhabited by adivasi groups, who count among the most marginalised in the country (Shah \& Lerche 2017). ${ }^{3}$ For these communities, mining operations have brought about dispossession, displacement, and the undermining of land- and forestbased livelihoods (see Fernandes 2007, 2008; George 2014; Lerche 2010; Levien 2018: Chapter 1; J ain \& Bala 2006). Around Karampot, too, mining has brought with it alienation of adivasi land. To make room for Pandu Project, which began 
construction in 1982, more than 3,000 acres of land had been acquired from seven villages. In addition to woodland and grazing fields surrounding Karampot, land acquisition included the entire tract of Dharutar, the neighbouring Santal village. When the building of the colliery began, Dharutar households had to surrender their agricultural plots; as per CCL's R\&R policy, those of them who lost at least three acres of such land were compensated with employment.4 This applied to 39 of the village's 49 households at the time, who received a permanent job in the new project

Dharutar's residential site, however - as well as areas of common, deedless land known as gair majurwa - remained intact, and life in the village carried on until 2008. In that year, it was announced that a new opencast mining pit would be excavated on Dharutar's entire remaining territory. At first, the village's forthcoming displacement generated protest by the community. Soon, however, this gave way to negotiations with CCL around more compensatory jobs, carried out by a local Santal neta (political leader) from the regionally dominant Jharkhand Mukti Morcha (JMM) party. Indeed, compensatory employment was this time around not a straightforward matter. Unlike in 1982, the land that was now about to be expropriated was not private but gair majurwa. Such land had been used informally, for either housing or cultivation, by most of the new households created in the village since the dispossession of all private land in 1982. Because it did not formally belong to them, however, gair majurwa land did not make villagers automatically eligible for compensation from CCL, which is normally given only for legally owned land. Santals from the newly created households, nevertheless - mostly from the younger generation - were eager to also obtain CCL employment.

For many of these Santals - and contrary to common narratives of 'accumulation by dispossession' (Harvey 2004) - the expansion of the colliery did not necessarily represent the destruction of a valorised rural way of life. Rather, it reflected a unique opportunity to exit the precarious conjunction of subsistence agriculture, faced with demographic pressure, and informal wage labour, and realise hopes of economic security through the possibility of a permanent, formal sector job. ${ }^{5}$ Indeed, when considering dispossession we cannot simply assume that people naturally prefer to till the land (see also Gardner 2018; Levien 2018). Younger Santals, in particular, tend to see agriculture as difficult and unrewarding. It provides neither livelihood 
security nor - equally importantly - cash earnings, which is what is needed for perusing emergent aspirations of class mobility and consumption.

Previous generations of adivasis often saw no reason to work more than was needed to meet their household's immediate, and relatively limited, consumption needs; they did not necessarily find the idea of regular employment appealing, and many preferred to farm their land (see also Bird David 1983; Parry 1999). Things, however, have certainly changed since. Population growth and generational land division have resulted in increasingly smaller landholdings, and the diminution of the role of land in rural household reproduction. Moreover, the gap between naukri and informal work has vastly widened: public sector posts in particular have become especially lucrative and competitive, virtually cut off from the sphere of informal labour. Lifestyle preferences and aspirations among adivasis, too, have been shifting: younger Santals, as I noted, are progressively less interested in agriculture and older village lifestyles, and increasingly harbour middle-class aspirations. Replacing one's mud dwelling with a concrete house, riding a motorbike rather than a bicycle, and sending one's children to a private school - these have become more common wishes among young Santals, which require a substantial, and preferably permanent, income. Consequently, jobs have become a highly sought-after - but scarce commodity.

Indeed, formal sector jobs in India are few and far between: while 92 percent of the Indian workforce are engaged in various forms of precarious informal labour, only eight percent have formal sector employment (Corbridge \& Shah 2013; HarrissWhite 2003, 2005; Harriss-White \& Gooptu 2001; Sridharan 2004). J onathan Parry (2013a, 2019) has asserted that this general divide is at present the most salient within India's labouring classes. Within the category of formal employment, sarkari naukri - public sector jobs, of the kind CCL provides - is considered the most secure and remunerative; those who have it thus constitute a privileged aristocracy of labour, well separated from the rest (ibid.; 2013a). For local Santals, relinquishing land for mining is seen as virtually the only way to penetrate this aristocracy's ranks - and, consequently, be able to pursue a more middle-class way of life. 
Indeed, the view among my interlocutors is that nowadays, the only imaginable path to attaining a public sector job in mining is through compensation for dispossessed land. Obtaining such employment through the standard application route does not seem to most local Santals like an option, for jobs normally require higher qualifications and skills than adivasis usually possess. In the mining industry in particular, mechanisation and downsizing of the permanent workforce as a result of liberalisation policies has resulted in a salient decline in job availability, especially for less-skilled labourers such as adivasis (Bhengara 1996; Chakroborty \& Narayan 2014; Fernandes 2007; Heuzé 1996: 229, 345; Heuzé 2009; Lahiri-Dutt 1999, 2014). Even the fact that, as a form of legally-sanctioned affirmative action, a proportion of state employment posts are reserved for adivasis does not provide my interlocutors with much comfort. Despite the reservation system, access to employment among most Santals in the area has remained limited. The common belief - not unnecessarily unfounded - is that the lion's share of reserved posts ultimately reaches a narrow stratum of better-connected, higher-class adivasis (see also Heuzé 1996: 247). Compared to such adivasis , most local Santals do not feel they have the necessary social capital and resources to successfully compete for jobs, and indeed many of them do not even try. Rather, the prevalent perception is that for them, the most (and perhaps only) feasible route to entering public sector employment is through being dispossessed of land.

The only way for Dharutar villagers, at this point, to be eligible for compensatory employment was to have the deedless land they had been using formally registered as their own, and on this basis claim compensation from CCL. The complex procedure of land titling was brokered, over the next couple of years, by the aforementioned neta. He collected money from villagers - gathered from years of savings and through loans from relatives - to grease the palms of the relevant local state officers; and, using the threat of peasant protest, pressed project management to find posts in the project for all newly-minted Santal land owners.

In total, 62 compensatory jobs were distributed, between 2012 and 2014, among the 69 households that had been added to Dharutar between the first phase of dispossession, in 1982, and the village's displacement. ${ }^{6}$ While some of the Santal employees have taken up residence in the CCL housing colony beside the colliery, 
others have relocated to Karampot, where they erected large cement houses. These employed households now make up about 10 percent of Karampot's 146 households. While Karampot's other villagers still retain their modest agricultural plots, they too have been affected by mining in different ways: from the coal dust that contaminates the air and soil, to the blasting that fractures the walls of their mud houses, to the enclosure of forest and grazing areas around the village. Because they have not been dispossessed of own land, however, they are not eligible for employment. Moreover, they have been offered no economic opportunities through the project, nor any other 'development' benefits such as paved roads or a village clinic. Instead, apart from scavenging coal for peddling, they only have access to casual wage labour in the mine's depot yard, loading coal on trucks for dispatch.

Given the general paucity of public sector employment in India and, more specifically, the coal industry's often poor track record in implementing R\&R programmes (Ahmad \& Lahiri-Dutt 2014; Herbert \& Lahiri Dutt 2004, 2014; J ain \& Bala 2006; McDowell \& Bennet 2012), the relatively large number of jobs that were handed out to displaced Santals from Dharutar can be considered a relative success. It has secured the livelihoods of a significant portion of displace Santals and, and I show in the next section, allowed them to pursue middle-class aspirations. But at the same time, as I will illustrate, the attainment of compensatory jobs has generated novel, enhanced forms of intra-Santal differentiation in Karampot, within a historically marginalised, relatively egalitarian community.

\section{Class differentiation}

\section{Jobs and salaries}

Every morning, most Karampot villagers leave their mud houses before dawn and walk to Pandu Project's depot yard, where coal extracted from the quarry is stored. Taking advantage of the absence of security guards in this early hour, and using metal bowls they bring with them, villagers try to gather as many lumps of coal as they can. Later, they will pack the coal into large jute bags, tie these onto their bicycles, and set off to the highway to peddle the coal to restaurants and informal petty coal brokers. 
On the other side of the village, Rajkumar's mornings look very different indeed. Long after other villagers have ventured out to the depot, in the dark, he sets out on his motorcycle to Pandu Project, where he is employed in the machinery workshop. Originally from Dharutar and now living in Karampot, 32-year-old Rajkumar had also used to peddle coal. In 2012, however, he gained a compensatory CCL job for dispossessed gair majurwa land in Dharutar. Like most Santals from Dharutar who attained CCL jobs after the village's displacement, Rajkumar works as a colliery workshop assistant - CCL's lowest, unskilled employment category, which is the standard starting point for those with a compensatory naukri. Higher employment categories involve more skilled work and increased pay, with employees normally moving up the scale based on experience and performance. Perhaps next year, Rajkumar hopes, he will be promoted to the next category, and work directly under one of the workshop foremen.

A number of Santals from Dharutar who got their jobs around 2012 have already gained such a promotion. A few of the more educated ones, who had completed secondary education, have even reached more advanced, non-manual positions. Rajkunar's friend Ramesh, for example, who had passed his Matriculation Exams, was posted in the Pandu Project office, where he works as a clerical assistant to the project's land surveyor. Higher-level posts in the project can also be found among the older-generation of Santal employees from Dharutar, who had gained their compensatory jobs in 1982: I know Santals who are workshop fitters, machine operators, and drivers, and one - Ramesh's father - who is a relatively senior office clerk. Supervisory and managerial positions in the project, on the other hand, are all occupied by higher-caste non-adivasis - often from outside the immediate area and even state - who generally have better qualifications and credentials than local Santals.

Santal employees, then, mostly inhabit the lower rungs of CCL's employment hierarchy - but, crucially, nevertheless enjoy the essential benefit of secure, permanent work, including prospects for promotion (at least up to a certain level). ${ }^{7}$ This makes them strikingly more privileged than all other, coal-peddling villagers in Karampot, who depend on work that is not only informal but illicit. While coal peddlers live a precarious existence, Santal employees gain from relative permanence 
and predictability, enabled through the job security that comes with a sarkari naukri. Their wages, too, are generous, and vastly superior to the earnings generated by coal peddling. Santals like Rajkumar, in CCL's lowest employment category, earn a monthly base salary of just over 13,000 rupees - equivalent roughly to 40 days of peddling coal. CCL wages, moreover, are accompanied not only by benefits such as free healthcare for the entire family and biennial holiday travel to an Indian destination of one's choice, but also a panoply of financial allowances that significantly augment one's actual income. These include, for example, 'conveyance allowance', 'children's education allowance', 'house rent allowance', 'breakdown allowance'8, and extra pay for night and weekend shifts.

These various allowances more than double employed Santals' income, taking it to north of 30,000 rupees. After deducting pension, gratuity, and provident fund contributions, they are left with about 26,000 rupees - a figure that would pass the muster as income for middle-class professionals in an average Indian town (Parry 2019: Chapter 5). CCL salaries also permit Santal employees to invest in side businesses, which further boost their income. Ramesh, for instance, has set up a small general store in the front room of his house, selling snacks, soap, and other basics, while another Santal employee I know has a rice hulling shop by the highway with a large electric husker.

Santal employees' high income, it should be added, is earned for work that is in fact not always very demanding - surely much less so than the backbreaking labour of peddling coal. On most days, for example, after signing in in the workshop in the morning, Rajkumar promptly heads to the nearby tea shop to have a cup of chai and chat with other colliery workers. Work in the workshop is mostly intermittent, based on machinery repair needs, and Rajkumar is not continuously needed on site. The same goes for Ramesh, who spends much of his workday hanging about the office, often chattering or joking with colleagues, and sometimes might even leave for a while to go run some personal errands. Indeed, similarly to what Parry (2013a, 2013b; Parry \& Strümpell 2008: 54) has observed in the Bhilai Steel Plant, jobs in Pandu Project are not only lucrative but typically involve only loose timekeeping and a relaxed work rhythm, which includes extended intervals of free time. 


\section{Consumption and lifestyles}

In the eyes of my coal-peddling interlocutors, those who have sarkari naukri are "forward" people - which is how, using the English word, they often refer to CCLemployed Santals. This 'forwardness' stands in contrast to non-employed villagers' 'backwardness', which is associated not only with precarious informal labour but more generally with adivasiness.

What, then, are the different elements of employed Santals' forwardness? To begin with, the relatively garish cement houses that a good number of them have erected in Karampot are startlingly distinct from the earthen houses of their neighbours - in material, size, colour, and overall splendour. Other distinction markers and consumption patterns have also emerged, reflecting employed Santals' pursuit of middle-class aspirations. These are especially prominent among the youngest generation of Santal employees, who gained their compensatory jobs in 2012-2014. Their houses' courtyards usually double as a parking space for a heavy duty motorcycle and/ or car, while their interiors might accommodate a not unsizeable flat screen television. The marriage celebrations they throw are lavish compared to the local adivasi standard of gathering and cooking with family and friends at home. The ones I got to attend included a decorated marquee, catering, and a small armada of hired jeeps transporting guests from other villages. In these wedding jamborees, young employed Santal men can be seen in (plastic) leather jackets, drinking bottled whiskey and rum rather than homebrewed rice beer and mahua wine. Indeed, diverging from the earlier, widespread adivasi practice of refraining from openly showing off one's wealth (Gell 1986; Shah 2018: 229), Santal employees' more wellto-do status is overtly demonstrated through consumption, producing the kind of distinction that is central to class aspirations (Qayum \& Ray 2011).

This is not to say, however, that Santal employees do not use their salaries for other types of investments, too. First, a few employees I know have purchased land around Karampot - either to farm, usually using hired labour; or, in the future, build a house on or set up some sort of small business. Second, considerable sums are spent on children's education, which is another significant marker of difference between CCLemployed households and all the rest. While coal-peddling households, too, devote resources to their children's education, their means are much more limited, and the 
level of education is consequently lower. Some coal-peddling households, for example, send their children to Holy Faith - the still-affordable private school on the other side of the highway, which might be superior to the local government school in Karampot but scarcely counts among the best in the district. Later on, coal-peddling youngsters might go to one of the many private colleges that have in recent years mushroomed in towns around Karampot, ${ }^{9}$ which are often of sketchy quality and reputation. This second-rate education trajectory already effectively eliminates children in coal-peddling households from the future race for formal employment.

Santal employees, on the other hand, can operate on a whole different scale: they send their children to relatively reputable - and considerably costlier - private schools and colleges in cities such as Hazaribagh, Ranchi, and Dhanbad, where students live in hostels or apartments that require additional fee or rent payments. In these schools and colleges, Santal employees hope, their children could attain the kind of educational qualifications that would place them in a better position to attain a job, and reproduce their parents' pay grade and status. ${ }^{10,11}$ Moreover, in marked contrast to the children of coal peddlers, who often skip school to help their parents with the gathering, coking, and loading of coal on the bicycle, those of employed Santals are not required to engage in any extra-household labour, and in principle can dedicate their time and energy to their studies.

Both consumption and investment in education, as expressions of middle-class aspirations, are also part of what Higham \& Shah (2013) have called a 'culture of emulation'. ${ }^{12}$ Higham \& Shah describe how young adivasis with public sector jobs in the education sector have begun to emulate the values, norms, and ways of life of higher-caste and -class groups. In Karampot, Santal CCL employees have been exposed to such ways of life through their daily work in the colliery, in which they chat and socialise - in the workshop, office, or tea shop - with non-adivasi, highercaste CCL workers. ${ }^{13}$ Employed Santals' culture of emulation, I would like to suggest, can have positive outcomes, for example with regard to education preferences. Take, for example, Puran, a Santal from Dharutar who had attained a CCL job in 1982. Talking about his children, Puran told me how before his employment, when he had been a "poor" and "simple" person, he "hadn't known anything about education". Working in Pandu Project, however, he got to know more "forward" non-adivasi 
colleagues who were sending their children to study in private colleges, "to give them a good education", and figured that this is something he could also do. Indeed, Puran later on sent his three children to attend a private college in Ranchi, where they are likely to gain qualifications that will improve their life chances and employability.

Alongside his studies, one of Puran's children is doing a traineeship in the block office, the most local unit of district administration. The daughter of another employed Santal from the 1982 cohort has completed a BA in accounting and has a job interview lined up in a local bank; the son of yet another has gained a diploma in electronic engineering in Hazaribagh, and is now preparing to take the exams for entry into the Indian Administrative Service (IAS). Indeed, a good number of the children of this cohort of Santal employees seem to be largely en route to reproducing the employment status of their fathers.

But at the same time, employed Santals' culture of emulation is creating new divisions and class hierarchies within the community: better-off Santals are increasingly moving towards becoming a local adivasi petty bourgeoisie, and distinguishing themselves from poorer community members who depend on precarious informal labour. Higher-class emulation has manifested locally across a range of practices - from preference of branded alcohol over homemade liquor, to travel by motorbike, to extensive wedding celebrations. While signs of such tendencies are also present among younger coal peddlers, and reflect broader generational shifts, it is among Santal employees that they are most developed and conspicuous. On the one hand, then, new employment opportunities in Pandu Project have allowed some Santals to access new, more middle-class domains - for example, in education and lifestyle - that had hitherto been largely closed to them. But on the other hand, they have acted to foster new, deeper inequalities within the Santal community - as well as, as I show below, within Santal families.

\section{Gender dynamics}

Class mobility and the culture of emulation have also had implications for labour and gender relations in CCL-employed households. The distribution of compensatory employment positions, to begin with, is decidedly gender-skewed: 'project-affected families' are taken by CCL to be represented by the male 'head of household', and it is 
to them that the jobs are given (see also Ahmad \& Lahiri-Dutt 2014; Mehta 2009; Mehta \& Srinivasan 2000; Thukral 1996). Second, in Santal employees' households gendered patterns of labour have emerged that are similar to those among caste Hindus, and distinct from those usually found in adivasi communities (Singh 1994). Adivasi women typically work outside the household. In coal-peddling households, for example, they have an indispensable role in this work: it is women who carry out most of the gathering of coal, which their husbands then load onto their bicycles for peddling. Moreover, women in these households usually also participate - whenever this is available - in casual truck loading wage labour in Pandu Project's depot yard, which provides them with access to independent wages. In CCL-employed households, on the other hand - more similarly to caste society ${ }^{14}$ - the participation of women in extra-household labour is decidedly less common.

Rajkumar's wife, Sikanti, is a characteristic example. Previously, like most women in the village, Sikanti had undertaken truck loading work, in order to both supplement household income and earn some pocket money for herself. But since Rajkumar gained his CCL job, in 2012-2014, Sikanti has stopped working and become a fulltime housewife; if she needs any cash, she now asks it from Rajkumar. Following the improvement of their financial situation, through Rajkumar's naukri, and since they do not need the extra cash, Sikanti prefers to engage in less labourious housework than go load trucks in the depot. Rajkumar, too, would rather his wife did not go out to work "in the sun and dust", but stayed at home. Indeed, in CCL-employed households women's participation in manual labour is generally viewed more dimly, which reflects an adoption of new - and more caste-like - notions of gender (see also Higham \& Shah 2013). The withdrawal of women like Sikanti from paid work can, of course, have both practical and personal reasons - higher household income through CCL salaries, for example, and personal work/ leisure preferences. I propose, though, that it also represents a way in which labour and more intimate practices in the home become a sphere in which to advance aspirations of class mobility (see Qayum \& Ray 2011: 247).

Research on the retreat of women in India from extra-household work has focused mostly on either higher-caste (e.g. Levien 2017) or dalit women (e.g. Kapadia 1995; Parry 2005, 2013b, 2019: Chapter 8; Still 2011, 2014). My findings from CCL- 
employed households Karampot indicate a similar pattern among adivasis, by showing how class mobility - in this case, as a result of compensatory employment for dispossession - can lead to women's disengagement from labour outside the house, and their increasing enclosure in the home. When enabled by material circumstances, in other words, adivasis too can edge towards a similar gender ideology to that of higher-status caste Hindus.

Class mobility, I suggest, has had contradictory consequences for women in CCLemployment households. To an extent - as has also been observed by Clarinda Still (ibid.; 2011) among higher-class dalit women in Andhra Pradesh - women in these households have gained new, 'forward' status vis-à-vis other Santal women in the village. But at the same time, and as a result of these women's retreat from paid work, their financial independence within the household has diminished. In CCLemployed households, that is - compared to coal-peddling ones - women's position in the gendered power dynamics has been altered. In coal-peddling households, women not only contribute to household earnings - through both coal peddling and truck loading work - but also usually keep the purse. CCL salaries, by contrast, are paid directly into the employed male's bank account, and it is they who largely control finances and manage the household budget. As has also been observed in other similar contexts (Ahmad \& Lahiri-Dutt 2014: 238), women in CCL-employed households consequently become increasingly dependent on the wages of their husbands, and swept aside in terms of household resource management. While in coal-peddling households, it is the norm for women to hold the purse strings, in CCLemployed households control over household money - by default in possession of the employed male - is a matter of individual negotiation. Women's position in CCLemployed households therefore stands in salient contrast to their position in coalpeddling households. In the latter, women play a central role in income generation and household reproduction - widely acknowledged by their husbands - and control household expenditure, which serves to enhance their financial and social independence. In CCL-employed households, conversely, women's withdrawal from any form of paid work, and their loss of control over the purse, undercuts their sovereignty. 
Unlike many private dispossessing projects, for instance, which usually do not provide work opportunities for women (e.g. Levien 2017), Pandu Project has been providing, through truck loading, such opportunities - however casual and unskilled. These, however, are only taken up by women from coal-peddling households, and relinquished by those from CCL-employed, more middle-class-oriented households. Non-manual work for women, on the other hand - which CCL-employed households might be less reluctant to accept - is not on offer. The result is that women in CCLemployed households have been withdrawn from the workforce altogether, and consequently become less independent and more reliant on their husbands financially. While adivasi women have historically been known to engage in labour outside the house and enjoy relative freedom and equality with men (Ahmad \& Lahiri-Dutt 2014: 238; Carrin-Bouez 1990; Devalle 1992; George 2014; Higham \& Shah 2013; Prasad 2016; Shah 2018), new notions of femininity among CCLemployed Santals have led to disapproval of such labour, and the effective relegation of women to the domestic sphere. Compared to previous generations in Karampot and other adivasis around them, in CCL-employed households Santal women have lost much of their autonomy, and new gender inequalities and dependencies have emerged.

\section{Household structures and disparities}

CCL employment and class mobility can have contradictory consequences not only in relation to household gender dynamics, but also household structure. These result from the tension between kin obligations, on the one hand, and emerging disparities within CCL-employed households, on the other. By and large, unlike caste society the adivasi convention is to live not in joint households, with the extended family, but in separate households with one's nuclear family (Elwin 1943). In Karampot, this is indeed the more common variant among coal-peddling households, with newlywed couples usually relatively quick to move out from the patrilocal household, or at least make plans to do so. Among CCL-employed households, however, the picture is somewhat different: though I lack comprehensive quantitative data, many of the CCL-employed households I know many are in fact joint, which in Karampot - and the adivasi context more generally - makes for an exception. On one level, this could be interpreted as another expression of class mobility aspirations, joint households being more typical of higher castes. ${ }^{15}$ But on another level, I suggest, such joint 
householding is also the outcome of a sense of moral responsibility by the employed household member - normally the father or elder brother - towards their nonemployed immediate kin, namely children or siblings. J oint householding, in this sense, is a way to ameliorate the intra-family differentiation produced through the attainment of a CCL job by only one member, which echoes adivasi egalitarian values.

It is common for Santals with CCL employment in Karampot - either currently employed or retired but with a CCL pension - to support close family members in the (joint) household. A few retired employees I know effectively finance, through their pensions, their adult sons and their own nuclear families, who reside with them in the same household. This is the case, for instance, with Kamal, whose household includes, apart from his wife, his three sons and their own wives and children. The son I know better, Surendra, whiles away most of his time pottering around the village, or betting on cricket matches and cockfights in a small nearby town. Peddling coal, which his brothers sometimes do, is "hard work" he prefers to avoid - especially as he can rely on his father's pension for subsistence. Indeed, Kamal's CCL pension 5,000 rupees a month - is used to purchase foodstuffs for the entire household, which covers all members' sustenance needs. Down the road from Kamal's house, in another CCL-employed joint household, the old retired Santal employee not only similarly finances household subsistence, but has also had a small grocery store, similar to Ramesh's, built in the courtyard for his son.

Several CCL-employed Santals I know who gained their jobs in 2012, after Dharutar's displacement, also inhabit joint households. Apart from themselves, their wives, and children, these households comprise the employees' younger, non-employed siblings and their own nuclear families, who are usually engaged in coal peddling. In these households, too, it is the employed sibling who largely provides for all members. Indeed, exchanging land for naukri entails a shift from collective property (land) and labour (coal peddling) to an individual asset (a CCL job), as usually it is only one brother who can get a job from the loss of land that was shared. A transition to naukri, in other words, involves a shift from a situation in which different household members till the soil and peddle coal together, to employment by a single member 
who carries the responsibility for the household's reproduction (see also Dhagamwar et al 2003: 56).

This responsibility can also extend to different kinds of financial assistance by the employed member to his siblings. Rajkumar, for instance, who also lives in a joint household, had helped one of his brothers to fund his wedding celebration a couple of years ago, and pays the school fees to Holy Faith for the two children of the other. This kind of redistribution is perceived in terms of a moral obligation by the elder brother - who by this virtue had been the receiver of the compensatory job - to look after his close kin who have not been as lucky. 16 "Rajkumar is the senior who has the naukri", his mother summarised the matter, "and has to take care of the house and his brothers".

At the same time, however, when it comes to lifestyle Rajkumar and his own nuclear family have diverged considerably from his siblings and theirs, and disparities within the household cannot be missed. Rajkumar and his siblings, for example, live under literally very different roofs. Adjoining the same central courtyard, Rajkumar's siblings occupy a mud house, whereas Rajkumar, his wife, and baby inhabit a newlybuilt cement structure with a flat screen television and speaker system. In the morning, while Rajkumar's brothers make their way to the depot and coking ground, he drives his motorcycle to the Pandu Project workshop. In the evening, while his brothers have a glass of rice beer at home, Rajkumar drinks Royal Stag whiskey or Old Monk rum in one of the highway restaurants around Karampot, often with friends from outside the village that he got to know through work. And, in a few years, Rajkumar's toddler will likely be sent to a better school - and then college than the one attended by his siblings' children. Indeed, compensatory employment as a result of dispossession has become a source of disparity not only at the level of the community, but also within families and households - in particular between siblings.

Notwithstanding the instances of intra-household redistribution that I encountered - from the employed brother to his non-employed siblings - even close kin cannot rely unconditionally on support from their employed relation. I know of several cases of "tension", as my interlocutors put it, within families around the extent and scope 
of kin obligations by the CCL-employed member. More specifically, the siblings of several CCL-employed Santals shared with me their disapprobation of their employed brother, for not having provided "enough help" to assist with a debt or health expenditure they had incurred. As I have pointed out, a CCL job - unlike land - is ultimately an individual entitlement, and CCL employees' salaries are intended to first and foremost serve them and their own nuclear families. Indeed, even Rajkumar's mother's words about his moral responsibility towards his siblings, cited above, were followed by a caveat. In the end, she pointed out, "one employed brother can't take care of his siblings forever".

Divergences within households with a CCL-employed member, then, certainly have the potential to give rise to feelings of rancour. Both Parry (2013b) and Dhagamwar et al. (2003: 128-131, 264) have found, in similar contexts, that over time relationships between the employed and non-employed sections of families become more acrimonious, and the limits of family obligation more constricted: the employed section progressively perceive their non-employed kin and their expectations of financial support as a burden, while these non-employed kin progressively harbour envy and grudges. Ultimately, Parry concludes, the 'axiom of kinship amity' (Fortes 1969) - the ethics of altruism and generosity predicated by kinship - is "vulnerable to the corrosive effects of class differentiation" (2013b: 53). While it remains to be seen whether or not the joint households of newly-employed Santals will stick together over time, my findings already indicate that one brother's class mobility - and consequent intra-family stratification - can put a strain on kinship relations, and thereby on joint householding. So, while the differentiation induced by CCL employment can in the first instance - contrary to adivasi custom act to keep families living together, in can also give rise to familial and intrahousehold friction that might eventually lead to joint households breaking up.

\section{Solidarity breakdown?}

Having so far focused primarily on the perspectives of Santal CCL employees themselves, I now turn to look at the ways in which their pursuit of middle-class aspirations are viewed by non-employed, coal-peddling villagers. Employed Santals' investments in new land and their children's education, for example, are mostly regarded by other villagers as worthy endavours. Younger employees' consumption 
patterns, on the other hand, attract more contrasting views, which diverge along generational lines. Younger coal peddlers tend to identify with the middle-class and consumption aspirations of their employed counterparts: throwing an elaborate wedding party or buying a new shiny motorbike, for them, are legitimate ways to spend one's money, and indeed things that they themselves would have liked to be able to afford.

Older non-employed villagers, on the other hand, are usually much more critical of such spending practices. They view the display of newly-acquired wealth by employed Santals - and, more broadly, intra-village differentiation - as detrimental to the community. In particular, they told me, differentiation has had a ruinous effect on "ekta" - translated as 'unity' or 'solidarity'. Simalal, for example, an older Santal from a coal-peddling household, wistfully described how before the days of sarkari naukri, marriages in the village had been celebrated as modest, down-home affairs, with home-cooked food and unostentatious gifts. The comparatively swanky wedding celebrations thrown by CCL-employed Santals are, in his eyes, profligate and gratuitous, intended mainly to impress and flaunt these Santals' new status as "big people" in the village. Such material display of prosperity, for Siamlal, is not only wasteful - a wedding party "only lasts for one day", the cars Santal employees buy "eventually break down and gather dust in the courtyard" - but also divisive. Display of wealth easily generates resentment among the worse off, who have been left behind in terms of class mobility and lifestyle. Compared to employed Santals, nonemployed villagers experience a sense of inferiority - for instance, for not being able to offer their own wedding guests what their well-do-to neighbours can ${ }^{17}$ - and consequently can feel compelled to spend beyond their means in order to 'catch up'.

Echoing the views of other non-employed Santals from his generation, Siamlal laments what he sees as a transition away from an agrarian community in which every villager had "one plate, one lota [water vessel] and one glass at home". For these elders, living off the land and forest, with everybody in the village roughly on the same footing, had promoted values of egalitarianism, reciprocity, and mutual aid. Now, by contrast, Karampot has become a place where newly prosperous villagers throw opulent wedding parties and drive around in motorcycles and SUVs - no longer adhering to the adivasi egalitarian consumption ethic previously documented 
by Alfred Gell (1986), whereby status display through conspicuous consumption was generally not aspired to. Instead of using their money to "help other villagers" or "develop the community", Siamlal said, employed Santals fritter it away on material goods to satisfy their own creature comforts and status desires.

Other older Santals, too, often employ memories of the past to comment on growing local inequalities and a shifting moral order. The disparities of the present, and resulting fissures in the social fabric, are counterposed with a forgone, "simpler" time that had been more egalitarian and harmonious. While Karampot's pre-mining days, had indeed been characterised by lower levels of differentiation, we should be conscious that such a contradistinction arguably involves a degree of romanticisation of the past, as people selectively evoke memories and elements from the 'old order' that juxtapose with disagreeable features of current reality. Nevertheless, the comparisons my older interlocutors draw between the present and their versions of the past reveal their idealised models of how the community should be. They feel that the social relations and moralities to which they attach value have been fraying, and relate this to the uneven inflow of wealth - that is, only to some households through CCL salaries, which has established local inequalities within Santals on a scale like never before.

As an alternative, older Santals imagine a different kind of adivasi society - one based on a political economy that does not stimulate self-interest and division. Siamlal, in this context, stresses the importance not of jobs but of land - not only for its material benefit as an inheritable asset or a long-term safety net, but because of the way of life and social relations it represents. Writing about Special Economic Zones in India, Jamie Cross has suggested that commitments to farmed land in contexts of dispossession are "not just commitments to custom or history" but commitments to ideas about particular futures and personhoods (2014: 57). Indeed, for Siamlal, an ideal future is not one of industrial employment but of agriculture not only as a form of livelihood or because of 'attachment' to land, but as emblematic of a moral order that stands in contrast to the corruptive indivisualisation and differentiation that have been unfolding in the community. 
One fragment of the bygone, more egalitarian world to which my older interlocutors refer, I would like to suggest, can be found in the Santal religious festivals held annually in the village. While, in their daily lives, these villagers mostly have no choice but to adapt to the unequal political economy around them, it is in ritual festivals that they can participate in the enactment of more egalitarian adivasi values. Indeed, instead of self-seeking and accumulation, community rituals foreground values of egalitarianism and resource sharing. Taking place in the sarna, the sacred grove at the edge of the village, Santal festivals revolve around the land and forest, and are meant to pay respect to all that they provide - from agricultural produce to mahua flowers. The ritual part of these festivals, officiated by the naike (village priest), involves the sacrifice of chickens to propitiate the village's spirits, in hopes for a good harvest and harmony in the community. Thereafter, all participants - coal peddlers and CCL employees alike - cook, eat, and drink together for hours in the sarna, in a context in which status distinctions seem to largely dissipate.

The spirit of egalitarianism is also reflected in the myths associated with the festivals. The traditional tale behind the Santal karam festival, for example, as told to me by a village elder, concerns two Santal brothers - Karma and Dharma - who lived in two neighbouring houses and cultivated adjacent patches of land. Whereas Dharma's plot required hard work and produced little, that of Karma had become very fertile and began producing abundant crops. Buoyed by his unanticipated success, Karma developed a condescending attitude towards his brother: after preparing his lunch, for instance, he would empty the remains of rice and water from the pot outside his house's window and onto Dharma's land. Soon thereafter, however, Karma's luck changed for the worse: his plot turned barren and unproductive, while Dharma's suddenly began to thrive. Karma's haughtiness, clearly, had reversed his fortune; the only way to rectify this, a wise old villager told him, was to leave the village and embark on a spiritual journey. In the beginning, Karma's bad luck seemed to follow him: the fruit he picked on the way were acrid, and the pond water he drank was foul. After weeks of walking, an angelic young boy finally appeared before Karma, instructing him to travel back home, plant a karam tree in the village, and worship it. Karma set out to return to the village, and the effect was immediate: already on the way back, the fruit he plucked were salubrious, and the water he fetched was sweet. 
As soon as he arrived in the village and planted the karam tree, his land regained its vitality.

As a parable about the deleterious consequences of disparity and vanity, the karam tale resonates with how many older coal-peddling Santals feel about employed villagers' display of status through consumption. It is, moreover, particularly explicit about the dangers of divergences within families and between siblings, which in Karampot have arisen as a result of dispossession and compensatory employment. Rituals such as karam, I propose, allow Santals not only to remember but also imagine an alternative, more egalitarian form of sociality, and serve as a moral resource for an ethical critique of processes of uneven accumulation and differentiation, and their corrosive impact on community ekta, or solidarity.

Cracks in solidarity - or, in other words, in the ethic of egalitarianism - have manifested in a number of areas. One of these, which I explore next, is madaiti - the adivasi custom of voluntary labour exchange between households - whose decline in Karampot provides one concrete example of the effects of internal differentiation.

\section{The decline of madaiti}

A form of reciprocal, non-monetary labour exchange, madaiti is typically practiced in adivasi communities in tasks such as sowing and harvesting of crops, and construction and maintenance of mud houses, and is considered a pillar of adivasi economics and society (e.g. Padel 2016; Shah 2010: Chapter 2, 2018: 136). In Karampot, while madaiti still takes place, it has been losing prominence in favour of other, monetary types of labour relations. In agriculture, for instance, madaiti is now in fact the least common labour practice. ${ }^{18}$ In-kind payment with rice crop is the most prevalent, followed by payment in cash - a relatively new phenomenon in the village.

A few decades ago, my older interlocutress recounted, madaiti in agriculture had been the norm. At the end of the workday, the owner of the field that had been jointly sown or harvested would serve mahua wine or rice beer, and sometimes a meal, to all labourers, who would drink and dine together. Now, however, much more of this work is done for a wage, and madaiti has become less widespread. In work on mud 
houses, too - for example, repairing or sealing the tiled roofs, especially before the rainy season - the use of madaiti has been waning while paid labour has become more common. Several interlocutors recalled that only a few years ago, this kind of work had taken place in their house through labour exchange. More recently, though, they had to pay to have their house's roof sealed - either to people from the village or to hired labour from outside of it. As one of the older coal peddlers said:

It's nowadays difficult to find even one person who's willing to help with something like this. Nobody wants to work for free. Even to help you push the coal on your bicycle up the slopes in the village, friends and relatives will ask for a portion of the earnings.

The decrease in madaiti and spread of cash payments seem to be an almost inescapable corollary of unequal accumulation and internal differentiation. It is mostly CCL-employed Santals who have started offering cash payments to nonemployed Santals for different kinds of work - not only agricultural, in employed Santals' vegetable gardens or small land plots, ${ }^{19}$ but also occasionally repair and renovation work in their cement houses. With their jobs and salaries, Santal CCL employees can certainly afford to pay a modest wage for such labour, and usually find this more convenient than having to reciprocate manually in their own free time for assistance from other villagers. Once it became clear to non-employed villagers that they can in fact get paid for this kind of work, they themselves have become generally more reluctant to do it without pay.

Not less importantly, economic differentiation has chipped away at the material basis for reciprocity, which is arguably essential for mutual aid practices. Coal peddlers and employed Santals now display radically different types of housing, financial capabilities, and needs. While the former inhabit mud structures with leaking clay tile roofs that require regular refitting, the latter occupy sturdy cement structures; while the former have limited financial resources, which can encourage engagement in labour exchange, the latter have the financial capacity to pay, which can contribute to a preference to hire labour. Such differentiation has pulled the rug from under the material foundation for reciprocity and mutuality, which many of my interlocutors feel had been crucial not only for household reproduction but more generally for 
social cohesion. As Kamal, the retired CCL employee, put it: "With madaiti, people had relationships (sambandh), a sense of togetherness (ek sath). Now, nobody here will work without getting paid. After the work, instead of eating and drinking together, people just take the money and go".

\section{Conclusion}

Focusing on a mining-affected Santal community in Jharkhand, this article has explored the effects of public sector employment - as a result of dispossession and compensation - on the lives of employed Santals and the community more broadly. It has shown how the attainment of sarkari naukri - and entry into the labour aristocracy of state employment - has allowed these Santals locally unprecedented levels of security and accumulation, and resulted among them in enhanced consumption patterns, improved education opportunities and life chances for children, and changes in gender and household relations. Pursuing middle-class aspirations and emulating higher-caste and -class ways of life, younger Santal employees have increasingly become a local petty bourgeoisie.

In parallel, however, compensatory public sector jobs have generated novel, starker forms of inequality within Santal society, as well as in employed Santals' own households. These new inequalities, it should be stressed, are not simply an accentuation of pre-existing, hitherto more subdued disparities; rather, by bringing employed Santals into the aristocracy of labour, public sector employment has engendered inequalities of a different qualitative order. Indeed, it has allowed these Santals to step over a threshold to new socioeconomic and class strata that other Santals in the locality, relying on precarious informal labour, can only dream of. As a consequence - and by contrast with the more common image of tribal societies as a bastion of egalitarianism - Karampot has seen the emergence of profound socioeconomic and class differentiation, between the minority of employed Santals and all the rest. While, compared to the caste-divided plains, economic differences between households in adivasi communities have historically been only "minimal and temporary" (Shah 2018: 229), CCL employment in Karampot has entrenched and cemented them. This, moreover, has been accompanied by emergent forms of consumption and wealth display that are similarly at variance with those usually ascribed to adivasis (e.g. Gell 1986; Shah 2018). 
Emerging disparities, I have suggested, have been undermining elements of adivasi society that revolve around an ethic of egalitarianism, displayed for instance in ritual festivals and instances of madaiti. These values are valorised in particular by the older generation, who lament their erosion through processes of individualisation and differentiation. These processes, for older Santals, are associated mostly with the political economy of mining, which has set the conditions for an unequal attainment by villagers of coal-related accumulation and class mobility opportunities. This perspective stresses the pernicious impact that new and overt forms of inequality have on egalitarian values and solidarity - exemplified for instance by the decline of the reciprocal labour exchange system of madaiti in favour of commodified intravillage labour relations. Such shifts in moralities are contrasted with a more egalitarian (if partly idealised) adivasi past, on which older Santals draw to articulate their critique of, on one level, the conduct of newly employed Santals, and, more broadly, the political economy that has been enfolding the community. Compensatory employment for dispossession have drawn some adivasis more firmly into the state's capitalist economic processes, encouraged them to adopt ideals of individual wealth and status accumulation, and become a source of stratification within adivasi society that chips away at its potentially counter-hegemonic, egalitarian elements. 


\section{Notes}

${ }^{1}$ Exceptions include Higham \& Shah (2013), Shah (1979), and Shah (2010).

2 My use of 'class' here and in subsequently is in the Weberian (1968 [1922]) sense of lifestyle, consumption, and life chances.

${ }^{3}$ Adivasis generally display high rates of poverty and underemployment, and engage in the lowliest types of work (see for example Breman \& Guérin 2009; Lerche 2007; Shah \& Harriss-White 2011).

4 The threshold for eligibility for compensatory employment has since then been lowered to two acres.

${ }^{5}$ On the dreams of development and particularly employment sparked by industrial projects, see Cross (2014, 2015) and Vijayabaskar (2010).

6 About a dozen households from Dharutar, who were not able to provide the money required for land registration, have been left without jobs. In this article, however, I focus mostly on those who did manage to obtain jobs.

7 This is at variance, for example, with findings about the jobs of adivasis who have entered state employment in the education sector, which were not only "relatively badly paid" but "insecure and dispensable" (Higham \& Shah's 2013: 4).

${ }^{8}$ For workers with duties for attending machine breakdowns at a short notice.

9 This has largely been the result of the liberalisation of higher education by the central government in the mid-2000s.

${ }^{10}$ Among coal-peddling Santals, by comparison, I know of only one child who is studying away in a college, through a special scholarship for adivasi students.

11 Similarly to consumption, investment in higher-quality education is more typical of the younger generations of Santal employees. Among the children of older-generation employees, education levels are in fact not all that different from those of the children in coal-peddling households. There are arguably two reasons for this. The first is a lower awareness of education in the older generation; the second is the lower lucrativeness of CCL wages in the past, compared to today. Wages at that time, Kamal told me, had not always sufficed to cover the fees of a good private school or college, not to mention student accommodation in a hostel or apartment.

12 Similarly to Higham \& Shah (2013), I use 'emulation' rather than sanskritisation (Srinivas 1956), which is defined as the rejection of low-caste customs and rituals to achieve upward caste mobility. This is because CCL-employed Santals are not relinquishing their Santal identity - say, through shunning local Santal festivals. Rather, they seek to add to this 
identity practices that are associated with higher castes and classes - which in their minds (and to an extent empirically) mostly overlap.

${ }^{13}$ On similar socialising between different castes in the Bhilai Steel Plant, see Parry (1999, 2013a, 2013b) and Parry \& Strümpell (2008: 54).

14 While women working outside the house is common among dalit communities and the elite, it is rare among all those in between (Singh 1994).

${ }^{15}$ Shah (1968) has long ago suggested that sanskritisation among adivasis tends to increase their proclivity towards joint householding.

16 While a sense of moral responsibility towards one's kin is also present in coal-peddling families, my point is that such a sense can become amplified in a context of differentiation within the family, i.e. when there is one employed sibling who earns considerably more than the others.

${ }^{17}$ Like with cases of tension within CCL-employed households, I do not mean to suggest that instances of envy had previously been absent in Karampot. I believe, however, that enhanced differentiation and the emergence of middle-class consumption patterns among employed Santals are likely to have made such instances more common and pronounced.

18 Based on household survey data and interviews.

19 Some CCL-employed Santals still have a small amount of 'leftover' family land in the vicinity; others, as I have mentioned above, have purchased new plots. Busy with their own CCL jobs, Santal employees usually do very little, if any, cultivation themselves, and instead hire agricultural labourers from either Karampot or outside of it. 


\section{References}

Ahmad, N. and K. Lahiri-Dutt. 2014. "Gender in Coal Mining Induced Displacement and Rehabilitation in J harkhand." In Coal Nation: Histories, Ecologies and Politics of Coal in India, edited by K. Lahiri-Dutt, 229-254. Farnham: Ashgate Publishing Limited.

Bailey, F. 1961. "'Tribe' and 'Caste' in India". Contributions to Indian Sociology 5: 719.

Bhengara, R. 1996. "Coal mining displacement." Economic and Political Weekly 31(2):647-649.

Bird-David, N. 1983. "Wage-gathering: Socio-economic change and the case of the Naiken of South India." In Robb, Peter. (ed.) Rural and South India: Linkages, Changes and Development. London, Curzon: 57-86.

Breman, J . and I. Guérin. 2009. "On bondage: old and new." In India's Unfree Workforce: Of Bondage Old and New, edited by J. Breman, I. Guérin and A. Prakash, i-xii. New Delhi: Oxford University Press.

Carrin-Bouez, Marine. 1990. Inner Frontiers: Santal Responses to Acculturation. Bergen, Norway: Chr. Michelsen Institute, Department of Social Science and Development.

Chakroborty, U.K. and B. Narayan. 2014. "Socio-economic issues and dilemmas of mining-induced displacement: a case of the coal mining industry." J ournal of Economic \& Social Development 10(2): 131-142.

CIL (Coal India Limited). 2008. "Resettlement and Rehabilitation Policy of Coal India Limited." www.centralcoalfields.in/indsk/pdf/employ land/land_rules/ r\&r_policy\%202008.pdf

Corbridge, Stuart and Alpa Shah. 2013. "Introduction: the underbelly of the Indian boom." Economy and Society 42(3): 335-347.

Cross, J . 2014. Dream Zones: Anticipating Capitalism and Development in India. London: Pluto Press.

Elwin, V. 1943. The Aboriginals. London: Oxford University Press.

Fernandes, W. 2007. "Mines, Mining and Displacement in India." In Managing the Social and Environmental Consequences of Coal Mining in India, edited by S. Gurdeep, D. Laurence and K. Kahiri-Dutt, 333-344. Dhanbad: The Indian School of Mines University.

Fernandes, W. 2008. "Sixty Years of Development-induced Displacement in India." In India Social Development Report 2008: Development and Displacement, edited by HM. Mathur, 89-102. New Delhi: Oxford University Press.

Fortes, M. 1969. Kinship and the Social Order. London: Routledge. 
Gardner, K. 2018. "We Demand Work!' 'Dispossession', patronage and village labour in Bibiyana, Bangladesh." The J ournal of Peasant Studies 45 (7): 1484- 1500.

Gell, A. 1986. 'Newcomers to the world of goods: consumption among the Muria Gonds". In The Social Life of Things, edited by A. Appadurai, 110-138. Cambridge: Cambridge University Press.

George, A S. 2014. Mining J harkhand, An Adivasi Homeland. A Status of Adivasis/ Indigenous Peoples Mining Series 2: J harkhand. New Delhi: Aakar Books.

Harriss-White, B. 2003. India Working: Essays on Society and Economy. Cambridge: Cambridge University Press.

Harriss-White, B. and N. Gooptu. 2001. "Mapping India's World of Unorganised Labour." Socialist Register 37: 89-118.

Harvey, D. 2004. "The 'New' Imperialism: Accumulation by Dispossession." Socialist Register 40: 63-87.

Herbert, T. and K. Lahiri-Dutt. 2004. "Coal Sector Loans and Displacement of Indigenous Populations: Lessons from J harkhand." Economic and Political Weekly 39(23): 2403-2409.

Herbert, T. and K. Lahiri-Dutt. 2014. "World Bank, Coal and Indigenous People. Lessons from Parej East, J harkhand." In Coal Nation: Histories, Ecologies and Politics of Coal in India, edited by K. Lahiri-Dutt, 145-164. Farnham: Ashgate Publishing Limited.

Heuzé, G. 1996. Workers of Another World: Miners, the Countryside and Coalfields in Dhanbad. New Delhi: Oxford University Press.

Heuzé, D. 2009. "Bondage in India: Representing the Past of the Present? The Case of the Dhanbad Coal Belt during the 1980s'.In India's Unfree Workforce: Of Bondage Old and New, edited by J . Breman, I. Guérin and A. Prakesh. 147-169. New Delhi: Oxford University Press.

Higham, R. and A. Shah. 2013. "Conservative force or contradictory resource? Education and affirmative action in J harkhand, India." Compare: AJ ournal of Comparative and International Education 43(6): 718-739.

Jain, S. and M. Bala. 2006. The Economics and Politics of Resettlement in India. New Delhi: Dorling Kindersley.

Kapadia, K. 1995. Siva and Her Sisters: Gender, Caste, and Class in Rural South India. Boulder: Westview Press.

Lahiri-Dutt, K. 1999. "State, Market and the Crisis in Raniganj Coal Belt." Economic and Political Weekly 34(41): 2952-2956. 
Lahiri-Dutt, K. 2014. "Introduction to Coal in India: Energising the Nation." In Coal Nation: Histories, Ecologies and Politics of Coal in India, edited by K. Lahiri-Dutt, 1-38. Farnham: Ashgate Publishing Limited.

Lerche, J . 2010. "From 'Rural Labour' to 'Classes of Labour': Class Fragmentation, Caste and Class Struggle at the Bottom of the Indian Labour Hierarchy." In The Comparative Political Economy of Development: Africa and South Asia, edited by B. Harriss-White and J . Heyer, 66-87. London: Routledge.

Lerche, J . and A. Shah. 2018. "Conjugated oppression within contemporary capitalism: class, caste, tribe and agrarian change in India." The J ournal of Peasant Studies 45(5-6): 927-949.

Levien, M. 2013. "The Politics of Dispossession: Theorizing India's 'Land Wars'." Politics \& Society 41(3): 351-394.

Levien, M. 2017. "Gender and land dispossession: a comparative analysis." The J ournal of Peasant Studies 44(6): 1111-1134.

Levien, M. 2018. Dispossession Without Development. Land Grabs in Neoliberal India. Oxford: Oxford University Press.

McDowell, C. and O. Bennet. 2012. Displaced: The Human Cost of Development and Resettlement. New York: Palgrave Macmillan.

Mehta, L and B. Srinivasan. 2000. Balancing pains and gains: A perspective chapter on gender and large dams. World Commission on Dams Thematic Review. Cape Town: World Commission on Dams Secretariat.

Mehta, L. 2009. "The double bind: A gender analysis of forced displacement and resettlement." In Displaced by development: Confronting marginalisation and gender injustice, edited by L. Mehta. 3-33. New Delhi: Sage Publications.

Nathan, D. and V. Xaxa. 2012. Social Exclusion and Adverse Inclusion: Development and Deprivation of Adivasis in India. New Delhi: Oxford University Press.

Padel, F. 2016. "Strengthening Adivasis' democratic rights over natural resources: Gram Sabhas and community management of resources in Orissa, Chhattisgarh and J harkhand." In Climbing India From Below. Activism and democratic transformation, edited by V. Mugdal, 87-102. New Delhi: Routledge.

Parry, J. 1999. "Lords of labour: Working and shirking in Bhilai." Contributions to Indian Sociology 33(1\&2): 107-140.

Parry, J . 2005. "Changing childhoods in industrial Chhattisgarh." In Educational Regimes in Contemporary India, edited by C. Radhika and P. J effery. 276-98. New Delhi: Sage Publications.

Parry, J . 2013a. "Company and contract labour in a central Indian steel plant." Economy and Society 42(3): 348-374. 
Parry, J . 2013b. "The 'Embourgeoisement' of a 'Proletarian Vanguard'?." In Interrogating India's Modernity: Democracy, Identity and Citizenship, edited by S.S. J odhka, 40-78. New Delhi: Oxford University Press.

Parry, J . 2019. Classes of Labour. New Delhi: Social Science Press.

Parry, J . and C. Strümpell. 2008. 'On the Desecration of Nehru's "Temples": Bhilai and Rourkela Compared'. Economic and Political Weekly 43(19): 47-57.

Prasad, A. 2016. "Adivasi Women, Agrarian Change and Forms of Labour in Neoliberal India." Agrarian South: J ournal of Political Economy 5(1): 20-49.

Qayum, S. and R. Ray. 2011. "The Middle Classes at Home." In Elite and Everyman: The Cultural Politics of the India Middle Classes, edited by A. Baviskar and R. Ray, 246-270. New Delhi: Routledge.

Shah, A. 2010. In the Shadows of the State: Indigenous Politics, Environmentalism, and Insurgency in J harkhand, India. Durham: Duke University Press.

Shah, A. 2018. 'Tribe, Egalitarian Values, Autonomy and the State'. In Critical Themes in Indian Sociology, edited by S. Srivastava, A. Yasmeen and J. Abraham, 225-239. New Delhi: Sage Publications.

Shah, A. and B. Harriss-White. 2011. 'Resurrecting Scholarship on Agrarian Transformations'. Economic and Political Weekly 46(39): 13-18.

Shah, A.M. 1968. "Changes in the Indian Family: An Examination of Some Assumptions." Economic and Political Weekly 3(1/2): 127-134.

Shah, A. and J . Lerche. 2017. "Tribe, Caste and Class - New Mechanisms of Exploitation and Oppression." In Ground Down by Growth: Tribe, Caste, Class and Inequality in Twenty-First Century India, edited by A. Shah, J. Lerche, R. Axelby, D. Benbabaali, B. Donegan, R. J ayaseelan and T. Vikramaditya, 1-32. London: Pluto Press.

Singh, K.S. 1994. The Scheduled Tribes. New Delhi: Oxford University Press in Collaboration with the Anthropological Survey of India.

Sridharan, E. 2004. "The growth and sectoral composition of India's middle classes: Their impact on the politics of economic liberalization." India Review 3(4): 405-428.

Srinivas, M.N. 1956. "A Note on Sanskritisation and Westernisation." Far Eastern Quarterly 15(4): 481-96.

Srivastava, V.K. 2008. "Concept of "Tribe' in the Draft National Tribal Policy." Economic and Political Weekly 43(50): 29-35.

Still, C. 2011. "Spoiled Brides and the Fear of Education: Honour and Social Mobility among Dalits in South India." Modern Asian Studies 45(5): 1119-1146. 
Still, C. 2014. Dalit Women: Honour and Patriarchy in South India. London: Routledge.

Sundar, N. 2001. "Debating Dussehra and Reinterpreting Rebellion in Bastar District, Central India." The J ournal of the Royal Anthropological Institute 7(1): 1935.

Thukral, E.G.. 1996. "Development, displacement and rehabilitation: Locating gender." Economic and Political Weekly 31(24): 1500-1503.

Throat, A. 2010. 'Ethnicity, Caste and Religion: Implications for Poverty Outcomes'. Economic and Political Weekly 45(51): 47-53.

Weber, M. 1968 (1922). Economy and Society: An Outline of Interpretive Sociology. Vol. 2. New York: Bedminster Press. 